\title{
CORROSION CONTROL OF ELECTROLYZER, ANOLYTE TANK AND DECHLORINATION TOWER TANK OF A CHLOR-ALKALI PLANT BY AN INNOVATIVE METHOD
}

\author{
Sazal Kumar Kundu* \\ Global Heavy Chemicals Limited (GHCL), Dhaka, Bangladesh
}

\begin{abstract}
Brine purification process of GHCL did not meet the specification of electrolyzer in the context of excess hydroxide ion $(\mathrm{OH})$. The electrolyzer, anolyte tank and dechlorination tower tank faced serious corrosion. This paper describes an innovative method adopted to meet the electrolyzer's specification of excess $O H$. This method consists of an innovative $\mathrm{HCl}$ dosing system added to purified brine tank. After adopting this method corrosion of electrolyzer, anolyte tank and dechlorination tower tank has been decreased in a noticeable rate. Also some chemical dosings have been reduced.
\end{abstract}

\section{Introduction}

Global Heavy Chemicals Limited (GHCL), a private company, produces mainly caustic soda and chlorine. This plant is located on the southern part of Dhaka district in Hasnabad Union under Keranigonj Thana. Keranigonj is on the south bank of the river Buriganga. This plant is producing 35 TPD caustic soda. Also this plant is expanding and it is expected that this plant will produce 50 TPD caustic soda in 2007 .

There are three processes for producing elemental chlorine, caustic soda and elemental hydrogen by decomposing sodium chloride solution (brine) electrolytically. The processes are: mercury cell process, diaphragm cell process and membrane cell process. GHCL selected membrane cell process (Figure 1). An ion-selective membrane separates anodic reactions from cathodic reactions in membrane cell process. Only sodium ions and a little amount of water pass through the membrane from the anode to the cathode compartment.

The main advantage of membrane cell process is the production of high purity caustic soda. But the disadvantage is the requirement of high quality brine. GHCL faced trouble to meet eletrolyzer's specification of excess $\mathrm{OH}^{-}$from the beginning of commercial production. The author analyzed data of brine purification unit, examined several options and finally solved the problem with a small change of process. This paper deals with how the problem was solved using an innovative idea.

\section{Brine Purification Process and the Problem}

The industrial grade salt used to prepare brine in GHCL is imported from India. This salt contains high quantity of impurities. The impurities are mainly calcium, magnesium and sulfate ions as shown in Table 1. So, the brine needs to be purified before using it for electrolysis. The brine purification process is shown in Figure 2. 30\% NaCl solution enters the anode side of electrolyzer. After electrolysis about $22 \%$ brine solution leaves the electrolyzer. Hydrochloric acid is added to this brine at anolyte tank to decrease its $\mathrm{pH}$ below 2. This decrease in $\mathrm{pH}$ helps in mechanical dechlorination by a steam ejector. After mechanical dechlorination sodium hydroxide and sodium sulphite are added to the dechlorination unit to remove chlorine fully from brine. The brine is then send back to salt saturator where its concentration rises to $30 \% \mathrm{NaCl}$. While leaving salt saturator the brine also receives salts of calcium, magnesium and other metals. Cations other than sodium ions must be removed according to the specification of electrolyzer's membrane. This brine then enters the brine purification reactor. Sodium carbonate and barium chloride are added to the reactor for removing calcium and sulfate ions successively. Sodium hydroxide and flocculant are added after brine

* Corresponding author's e-mail: saza194@yahoo.com 
purification reactor. Sodium hydroxide removes magnesium ions from brine. After reaction total hardness of brine reduces to ppm level (below 10ppm). This brine is then sent to brine clarifier, anthracite filter and finally candle filter to remove suspended solids. After passing through these units chemical compositions of the brine remain unchanged. Then the brine enters ion-exchange columns where total hardness reduces to ppb level (below 20ppb). But excess $\mathrm{OH}^{-}$content remains unchanged. This is the purified brine for the electrolyzer. According to the electorlyzer's specification, excess $\mathrm{OH}^{-}$should be less than $200 \mathrm{mg} / \mathrm{liter}$. But excess $\mathrm{OH}^{-}$was more than 1200 $\mathrm{mg} / \mathrm{liter}$ in the purified brine of GHCL. As a result, the electrolyzer, anolyte tank and dechlorination tower tank faced serious corrosion. And GHCL faced frequent shutdown.

\section{Options to Solve the Problem}

The author considered the following options to solve the problem:

- Controlling $\mathrm{NaOH}$ dosing in dechlorination unit and after brine purification reactor

- Adding $\mathrm{HCl}$ to purified brine tank before sending brine to electrolyzer

The first option was not feasible. This option was tried to put but total hardness of brine before clarifier increased (above 10ppm). As a result, total hardness of brine after ion-exchange columns increased (above $40 \mathrm{ppb}$ ). And the second option was finally selected to solve the problem.

Implementing second option involved additional equipment and chemicals. The author was planning to do something very simple and cost-effective. The author found two ways to implement the second option. They are:

- Online mixing of $\mathrm{HCl}$ and brine after ionexchange column

- Mixing by agitation of falling liquids, $\mathrm{HCl}$ and brine, through a hollow pipe from the top of the purified brine tank
The first way needs a pump, which is costly. So, the second way was chosen. One $\mathrm{HCl}$ tank is placed in GHCL dechlorination unit building at above 45 $\mathrm{ft}(13.7 \mathrm{~m})$ height. This tank was connected with purified brine tank to add $\mathrm{HCl}$ with brine through potential energy using the arrangement shown in Figure 4. (Height of purified brine tank is $17 \mathrm{ft}(5.2 \mathrm{~m})$.)

\section{Implementing the Scheme}

The schematic diagram for implementing the scheme is shown in Figure 4. One hollow pipe of $152 \mathrm{~mm}$ ID has been used here. Another pipe of $25 \mathrm{~mm}$ ID is passed through this hollow pipe. Brine is passing through the hollow pipe and $\mathrm{HCl}$ is passing through the narrow pipe with the help of a rotameter. At the bottom of the hollow pipe a good mixing takes place from agitation of falling liquids. One $\mathrm{pH}$ meter was installed from top of the purified brine tank. The $\mathrm{pH}$ meter is sensing at $70 \%$ level from the bottom of the tank. It could be mentioned that this tank is always maintained above $90 \%$ level.

When the scheme was put into operation excess $\mathrm{OH}^{-}$of the purified brine met the specification of the electrolyzer.

The data on $\mathrm{HCl}$ consumption at purified brine tank after operating with the new scheme are given below:

- Concentration of $\mathrm{HCl}: 18 \%, \mathrm{w} / \mathrm{w}$

- Range of Brine Flow Rate : $10-15 \mathrm{~m}^{3} / \mathrm{hr}$

- Requirement of $\mathrm{HCl}: 60-80$ liter $/ \mathrm{hr}$

The plant is operating successfully with this modification. And GHCL has achieved some advantages after implementing the scheme.

\section{Achievements}

The frequent leakage of electrolyzer, anolyte tank and dechlorination tower tank has been stopped. Before implementing the scheme GHCL used to be shut down for serious corrosion of these units (electrolyzer, anolyte tank and dechlorination tower tank) once in a week. And after implementing the scheme GHCL 
rarely shut down for corrosion problem of the above mentioned units and there is very little corrosion.

Besides having the above improvements GHCL achieved some benefits from this modification. As can be seen from Table 2 the other benefits are:

- Less consumption of sodium hydroxide in brine dechlorination.

- Less consumption of hydrochloric acid in anolyte tank.

- Less consumption of sodium sulfite in brine dechlorination.

- Less consumption of barium chloride in brine purification unit. Barium chloride is used to decrease $\mathrm{SO}_{4}{ }^{=}$content in brine. High content of $\mathrm{SO}_{4}{ }^{=}$ions can affect the electrolysis process.

- Less consumption of flocculant.

- Sodium Chlorate $\left(\mathrm{NaClO}_{3}\right)$ content of brine has been decreased. $\mathrm{NaClO}_{3}$ is corrosive to metals. The decrease in content of this compound is beneficial for plant operation.

\section{Acknowledgements}

The author would like to thank Mr. Dipak Kumar Kundu (Project In-Charge of GHCL) for giving permission to carry out this work and providing helpful suggestions. The author also thanks all personnel of process area and QC of GHCL for their assistance.

\section{References}

1. Plant Documents of Global Heavy Chemicals Limited.

2. Chlor-Alkali Process :

$<$ www.akerkvaerner.com/Internet/IndustriesA ndServices/Pulping/BleachingChemicals/Chlo ralkaliProcess.htm $>$

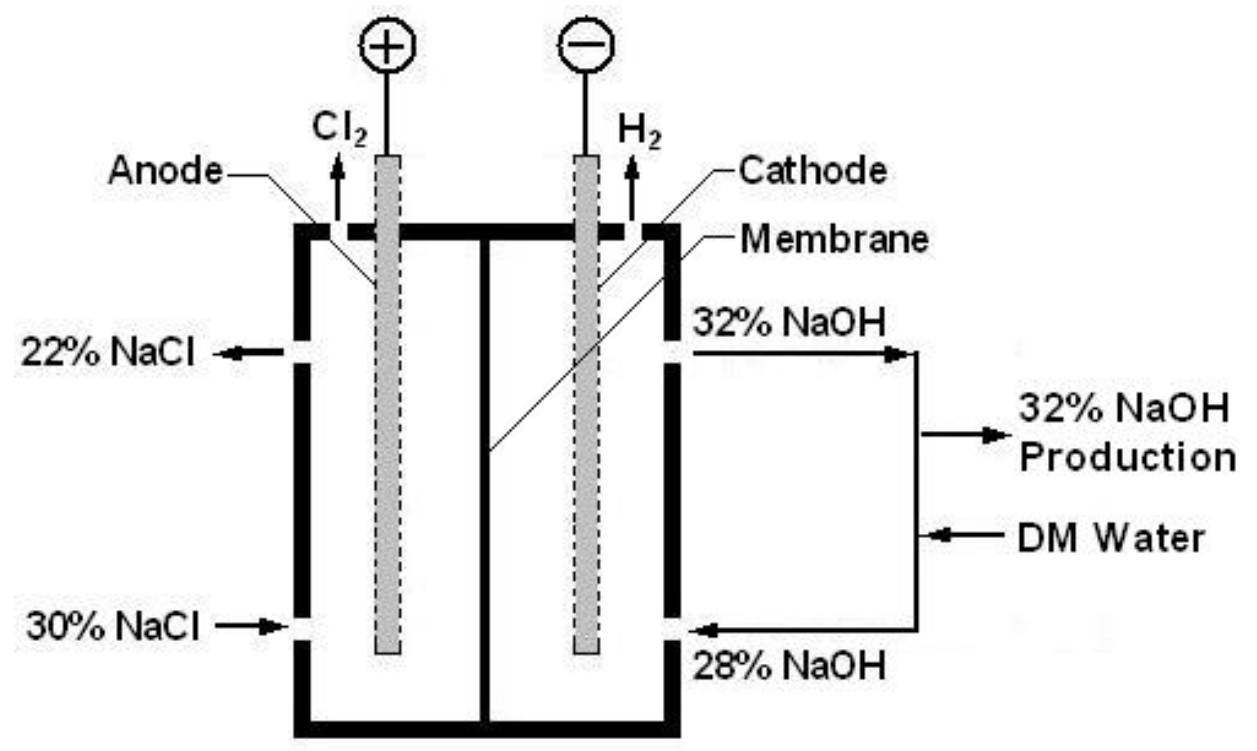

Fig. 1: Membrane cell process to produce sodium hydroxide, hydrogen and chlorine. 


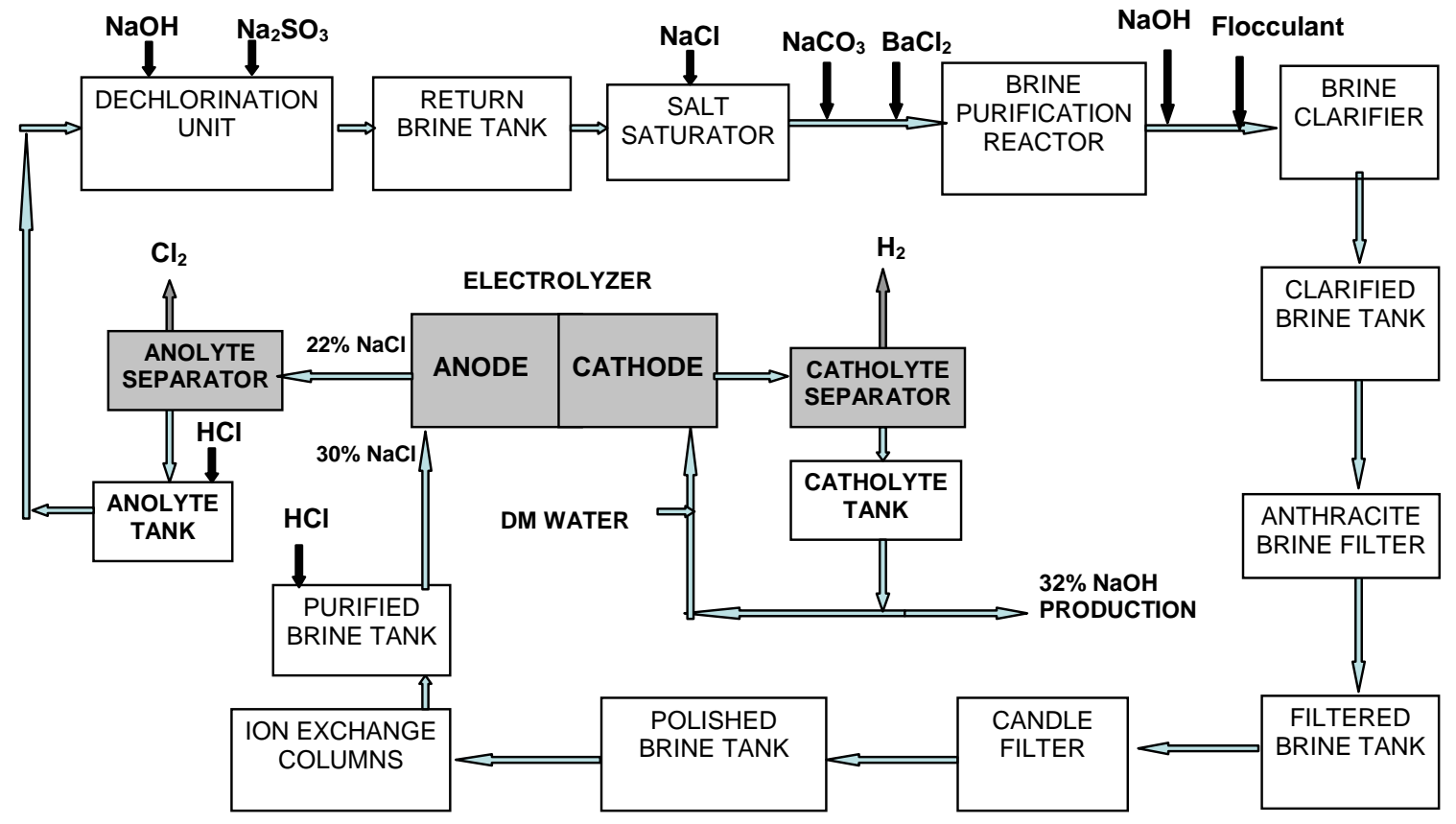

Fig. 2: Block diagram of brine purification process and electrolysis including the modification

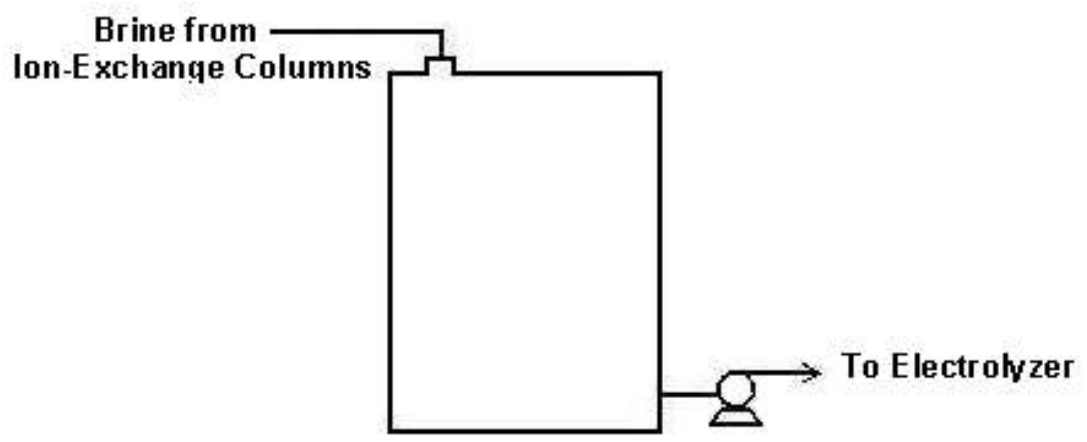

Fig. 3: Schematic diagram of purified brine tank (before the modification) 


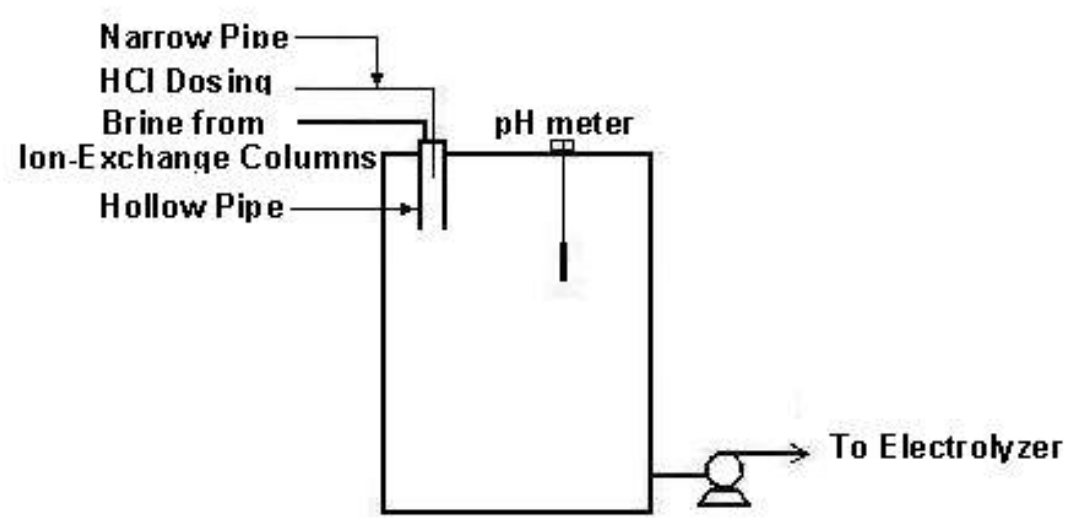

Fig. 4: Schematic diagram of purified brine tank (after the modification)

Table 1: Salt composition (imported from India)

\begin{tabular}{|l|l|l|l|l|l|}
\hline Date of Test & $\mathrm{Ca}^{++}$ & $\mathrm{Mg}^{++}$ & $\mathrm{SO}_{4}{ }^{+}$ & $\mathrm{NaCl}$ & Moisture \\
\hline 23.04 .05 & $0.211 \%$ & $0.035 \%$ & $0.411 \%$ & $95.28 \%$ & $3.23 \%$ \\
\hline 01.06 .05 & $0.18 \%$ & $0.022 \%$ & $0.361 \%$ & $96.14 \%$ & $2.64 \%$ \\
\hline
\end{tabular}

Source: QC, GHCL

Table 2: Improvement after implementing the new scheme

\begin{tabular}{|c|c|c|c|c|}
\hline Serial No. & Parameter & $\begin{array}{l}\text { Before operating } \\
\text { with new scheme } \\
\text { (July 18, 2005) }\end{array}$ & $\begin{array}{l}\text { After operating } \\
\text { with the new } \\
\text { scheme (August } \\
\quad 06,2005 \text { ) }\end{array}$ & Source \\
\hline 1 & $\begin{array}{l}\mathrm{NaOH}(32 \%, w / w) \text { Dosing to } \\
\text { Dechlorination Tower Tank }\end{array}$ & $60 \mathrm{liter} / \mathrm{hr}$ & 20 liter/hr & \multirow{5}{*}{$\begin{array}{c}\text { Brine } \\
\text { Purification } \\
\text { Unit, GHCL }\end{array}$} \\
\hline 2 & $\begin{array}{l}\mathrm{HCl}(18 \%, \mathrm{w} / \mathrm{w}) \text { Dosing to } \\
\text { Anolyte Tank }\end{array}$ & 150 liter/hr & 110 liter/hr & \\
\hline 3 & Sodium Sulfite Dosing & $525 \mathrm{~kg} /$ day & $225 \mathrm{~kg} /$ day & \\
\hline 4 & Barium Chloride Dosing & $860 \mathrm{~kg} /$ day & $270 \mathrm{~kg} /$ day & \\
\hline 5 & Flocculant Dosing $(0.07 \%, \mathrm{w} / \mathrm{v})$ & 57.6 liter/hr & 36 liter/hr & \\
\hline 6 & $\mathrm{NaClO}_{3}$, Purified Brine & $11.50 \mathrm{gm} / \mathrm{liter}$ & $7.80 \mathrm{gm} / \mathrm{liter}$ & \multirow[t]{2}{*}{$Q C, G H C L$} \\
\hline 7 & $\mathrm{SO}_{4}{ }^{2}$ content, Brine after Clarifier & $8.00 \mathrm{gm} / \mathrm{liter}$ & $5.6 \mathrm{gm} /$ liter & \\
\hline
\end{tabular}

N.B.: Brine purification process of GHCL has been operating with the new scheme from July19, 2005 